\title{
Fiscal consequences of the abolition of sugar levies ${ }^{1}$
}

\author{
Maciej Cieślukowski ${ }^{2}$, Mihai Mutascu ${ }^{3}$
}

\begin{abstract}
From October 2017 the European Union envisages the abolition of the socalled sugar quotas and minimum prices for buying sugar beet. As a consequence of these changes the sugar levies paid by the sugar factories of the Member States will cease to apply. The article identifies the fiscal effects of the abolition of these levies. The European Union and the Member States will lose some of their budget revenues. The structure of Member States' burdens for GNI payments will also change as well as their operating balance relative to the EU budget. Through the change Poland will gain, whereas some large net contributors will lose, i.e. the Netherlands, Sweden and the United Kingdom.
\end{abstract}

Keywords: sugar levies, sugar market, EU budget, net contributors and beneficiaries. JEL codes: F 55, H27, Q18.

\section{Introduction}

From October 2017 the European Union envisages the abolition of the socalled sugar quotas (limits for Member States in the production of sugar, glucose and inulin syrup) and the minimum prices for buying sugar beet (Council Regulation of 16 December 2013). These changes are part of the reform of the agricultural market initiated in 2013 towards further liberalization and adaptation to global conditions (World Trade Organization, 2016; European Commission, 2013). As a consequence of these changes, sugar levies paid by sugar factories will cease to apply. The European Union will lose one of the types of so-called own resources.

The aim of the paper is to identify and assess the fiscal consequences of the abolition of sugar levies for both Member States and the European Union. In the first three sections the structure and economic importance of sugar levies was approximated. In the next two sections a fiscal impact analysis was carried

\footnotetext{
${ }^{1}$ Article received 12 April, accepted 24 September 2018.

${ }^{2}$ Poznań University of Economics and Business, Public Finance Department, al. Niepodległości 10, 61-875 Poznań, Poland, m.cieslukowski@ue.poznan.pl.

${ }^{3}$ ESCE International Business School Paris, 10 Sexius Michel, 75015, Paris, France.
} 
out for the Member States and the EU on the basis of simulations of changes in the budget conditions in force in 2013.

\section{Types of sugar levies}

Sugar levies have been serving the general budget of the European Union since 1971 and belong to the so-called own resources of the Union (Council Decision of 21 April 1970). They are imposed directly on producers of sugar, isoglucose and inulin syrup. There are several types of sugar levies. The most important is the production levy charged in euros per ton of manufactured product with the Union setting production limits (sugar quotas) for each country, which divide the allocated limits between sugar factories. EU regulations allow sugar factories to transfer up to $50 \%$ of the production fee to sugar beet and cane growers and chicory suppliers. Enterprises are obliged to pay production levies by the end of February of a given marketing year at the latest.

In addition to the production levy there are also levies for storing stocks, sanction levies and one-off additional levies. In the years 2006-2009 there were also special restructuring levies (contributions) qualified in the budget for the so-called assigned revenue for particular aims (Council Regulation of 20 February 2006). Sugar levies have changed over the years depending on EU policy. Table 1 presents the types and amount of sugar levies in force in 1999/2000-2016/2017.

Sugar levies are collected and paid to the EU budget by the Member States. For this reason they may retain part of the collected funds to cover administrative costs. ${ }^{4}$ The amount of these costs has changed over the years. In 1971-2001 , it was set at $10 \%$ of revenue collected, in 2001-2013-at $25 \%$ of revenue, and since 2014 it is $20 \%$ of revenue earned. ${ }^{5}$

\section{The purpose of sugar levies}

Sugar charges are a derogation from the budgetary principle of material unity because they are purposeful. Revenues from these levies are allocated solely to support the internal sugar market and are to ensure responsible participation of sugar factories and sugar beet growers in financing this market. This means that the collected funds should cover expenditure on this market and thus ensure the neutrality of the mechanism against the EU budget (European

\footnotetext{
${ }^{4}$ The costs do not occur in the case of restructuring levies.

${ }^{5}$ The research shows that these costs are much higher than the actual costs of collecting the levies and can be treated as a fiscal relief for the largest payers, i.e. mainly Belgium, the Netherlands, Germany and the United Kingdom (Cieślukowski, 2013).
} 
Table 1. Types and amounts of EU sugar levies in the years 1999/2000-2016/2017 (euro/ton of a product)

\begin{tabular}{|c|c|c|c|}
\hline \multicolumn{2}{|c|}{ Type of levy } & $1999 / 2000-2005 / 2006$ & $2006 / 2007-2016 / 2017$ \\
\hline \multirow{6}{*}{$\begin{array}{l}\text { Production } \\
\text { levy }\end{array}$} & Sugar A & 12,60 & \multirow{2}{*}{$\begin{array}{l}12,00 \\
12,00\end{array}$} \\
\hline & Sugar B & 12,60 & \\
\hline & Izoglucose A & 12,60 & \multirow{2}{*}{$\begin{array}{l}6,00 \\
6,00\end{array}$} \\
\hline & Izoglucose B & 12,60 & \\
\hline & Inulin syrup A & 12,60 & \multirow{2}{*}{$\begin{array}{l}12,00 \\
12,00\end{array}$} \\
\hline & Inulin syrup B & 12,60 & \\
\hline \multirow{3}{*}{$\begin{array}{l}\text { Restructuring } \\
\text { charge }\end{array}$} & Sugar & - & $\begin{array}{l}126,40(2006 / 2007) \\
173,80(2007 / 2008) \\
113,30(2008 / 2009)\end{array}$ \\
\hline & Isoglucose & - & $\begin{array}{l}63,20(2006 / 2007) \\
86,90(2007 / 2008) \\
56,65(2008 / 2009)\end{array}$ \\
\hline & Inulin syrup & - & $\begin{array}{l}126,40(2006 / 2007) \\
173,80(2007 / 2008) \\
113,30(2008 / 2009)\end{array}$ \\
\hline \multirow{5}{*}{ Other levies } & $\begin{array}{l}\text { From the granted ad- } \\
\text { ditional production } \\
\text { amount (one-off pay- } \\
\text { ment) }\end{array}$ & - & 730,00 \\
\hline & $\begin{array}{l}\text { Production fee over the } \\
\text { allocated limits }\end{array}$ & - & 500,00 \\
\hline & Storage charges & - & $\begin{array}{l}\text { The highest customs } \\
\text { tariff on sugar im- } \\
\text { ports (respectively } \\
\text { isoglucose) in the } \\
\text { period from May 1, } \\
2004 \text { to April 30, } 2005 \\
\text { multiplied by EUR } \\
1,21 / 100 \mathrm{~kg}\end{array}$ \\
\hline & Sugar B & 237,00 & - \\
\hline & $\begin{array}{l}\text { Levies on non-exported } \\
\text { production intended } \\
\text { for export (C sugar, } \mathrm{C} \\
\text { isoglucose })\end{array}$ & - & EUR $1725,00 / 100 \mathrm{~kg}$ \\
\hline
\end{tabular}

A - sales to the EU market.

B - export outside the EU.

$\mathrm{C}$ - production for export but not exported.

Source: based on (Council Regulation of 16 December 2013 and Cieślukowski, 2013). 
Commission, 2011a; Agencja Rynku Rolnego, 2004). However the specific objectives of sugar levies have changed significantly since the 2006 sugar reform. Prior to the reform revenues from production levies were primarily intended for co-financing the export of sugar products and for subsidies to sugar used in the chemical industry. On the other hand the levies on inventories were used to cover the costs of sugar storage and in this way were to secure the appropriate amount of sugar on the internal market. The indicated levies indirectly also guaranteed profitable prices for sugar beet growers who were guaranteed minimum prices at which sugar factories purchased sugar beet. Sanction levies and additional one-off charges were of a supplementary character and as a rule resulted from unplanned costs or the granting of additional production quotas. Empirical data, however, indicate that the mechanism of self-financing of the market was not entirely effective. Figure 1 presents the total budget expenditure on the sugar market in comparison with the amount of sugar levies collected in 2001-2013.

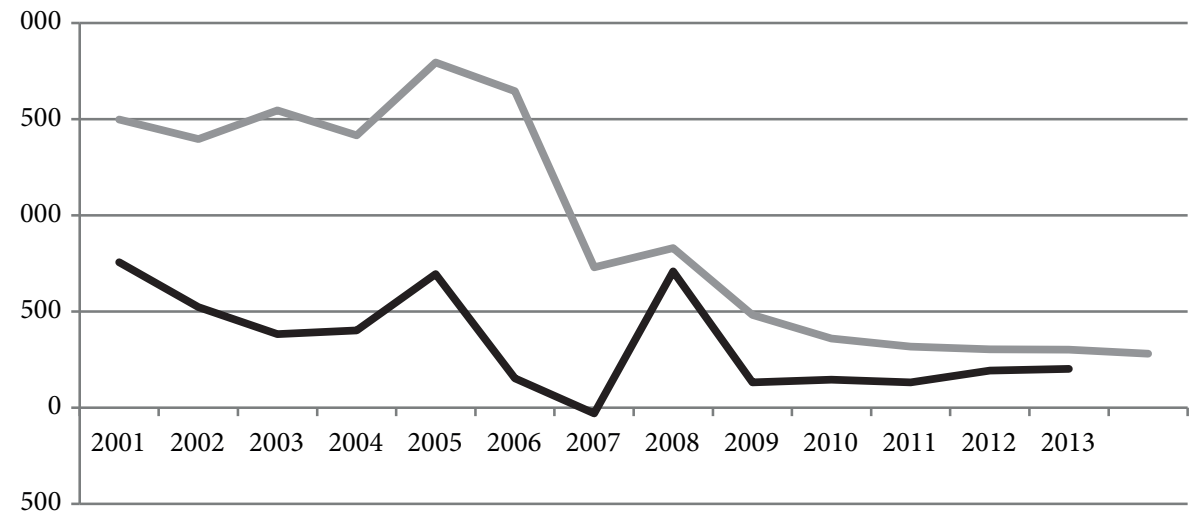

$\longrightarrow$ Revenues from sugar levies $\longrightarrow$ Expenditure on the sugar market

Figure 1. Total budget expenditure on the sugar market compared to the revenue from sugar levies in 2001-2013 (EUR million)

Source: based on (European Commission, 2014a, 2008a).

The clear advantage of spending over the revenue collected before the reform was a compilation of several factors, the most important being the costs of sugar policy for many years aimed at protecting the internal market and ensuring profitability of production. The gap was also increased by the increased administrative costs of collecting traditional revenues from 10 to $25 \%$ from 2001 and the enlargement of the Union by new countries in 2004. The latter led to a major over-production of sugar in the internal market and, consequently, increased the gap between the costs of maintaining the market and the revenues from sugar levies. 
In 2006 the reform of the sugar sector was initiated in the direction of reducing production, increasing competitiveness and adapting to international conditions (Directorate-General Agriculture and Rural Development, 2011). The essence of the reform was expressed in the replacement of the mechanism of price and revenue support with direct payments integrated with the entire aid system under the common agricultural policy (Ministerstwo Rolnictwa i Rozwoju Wsi, 2011). As a result, from 2011, subsidies on sugar exports and subsidies on stocks have basically ceased. The costs of limiting and diversifying production were financed from a temporary restructuring fund provided with special restructuring charges. These levies were paid by the sugar factories to the sugar quotas granted. The fund had funds in excess of EUR 6.2 billion, and the total amount of aid in 2007-2012 amounted to almost EUR 5.5 billion. Finally the restructuring ended with a reduction in the number of sugar holdings from 74 to 56, sugar factories - from 183 to 106, and farms growing sugar beet - from 251.4 to 162.3 thousand (Comite Europeen des Fabricants de Sucre, 2010). The main beneficiaries of the restructuring aid were Italy, Germany and France. The largest negative effects of the reform were felt by Poland, where by the end of the 2009/2010 marketing year, among others 38 out of 56 sugar factories were closed (Directorate-General Agriculture and Rural Development, 2011; Ministerstwo Rolnictwa i Rozwoju Wsi, 2011). Since 2011 the EU sugar market has been more stable and is characterized by a more effective selffinancing mechanism. Figure 1 shows that revenue from sugar levies almost offset the expenditure on the sugar market.

\section{Fiscal significance and main payers of sugar levies}

In the years 1971-2013, sugar levies were not an efficient fiscal source and were also characterized by instability. Revenue from levies increased in general up to the second half of the 1980s, after which in successive years they gradually decreased. Figure 2 presents the fiscal performance of sugar levies in the years 1971-2013, measured by their share in total budget revenues.

In the years 1971-1987 the revenue from sugar levies increased from 95.5 million to almost EUR 1.5 billion, which accounted for 2.7 and $4.2 \%$ of total budget revenues, respectively. A significant increase in revenues was usually recorded after the enlargement of the Communities to include new Member States and an increase in the number of sugar factories, ie after 1973 (Great Britain, Ireland and Denmark), 1981 (Greece) and 1986 (Spain and Portugal). In the 1990s the revenue was characterized by the relative stability of over EUR 1 billion, however, as a result of the introduction of GNI payments in 1988, their productivity was constantly decreasing. After 2000 the additional decrease in productivity resulted mainly from the lower revenue caused by the increase in the cost of payment of traditional resources from 10 to $25 \%$. Another clear 


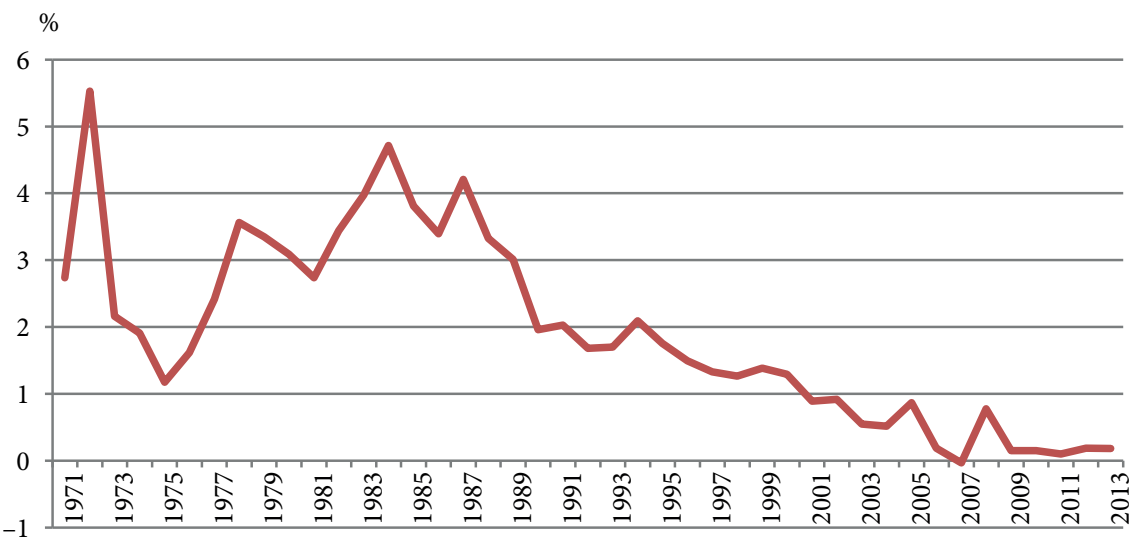

Figure 2. Fiscal efficiency of sugar levies in 1971-2013 measured by their share in total budget revenues (\%)

Source: based on (European Commission, 2014b; European Union, 2006).

decline and fluctuations in the fiscal performance of levies were noted after the 2004 enlargement and they were the result of the previously indicated reform of the sugar sector. In 2007 negative revenues of -30.7 million euros $(-0.03 \%$ of total budget revenues) meant a surplus over reimbursements to Member States. Returns rose from the revaluation and collection of excessive levies in 2006 (European Commission, 2008b). On the other hand a clear increase in revenues in 2008 resulted mainly from the imposition of one-off levies (almost 540 million euros) on additional inulin production quotas. Since 2011, after the market stabilizes, only the production levy and the excess production charge are collected (Figure 3). Revenue from these levies rose significantly from over

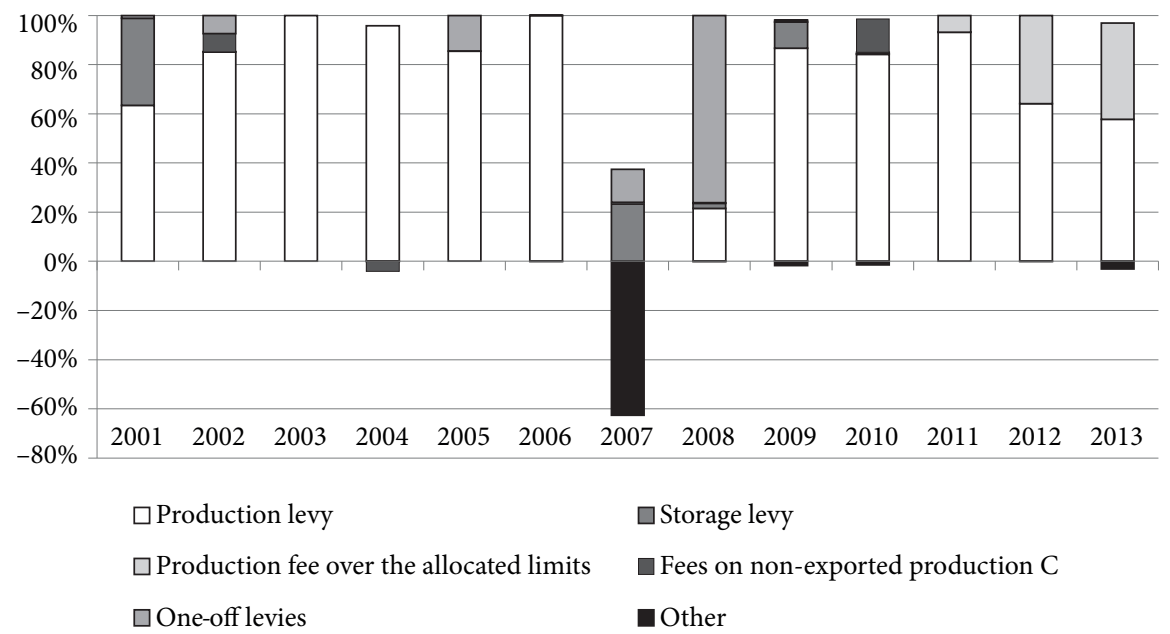

Figure 3. Structure of revenues from sugar levies in the years 2001-2013

Source: based on Budżet on line. 


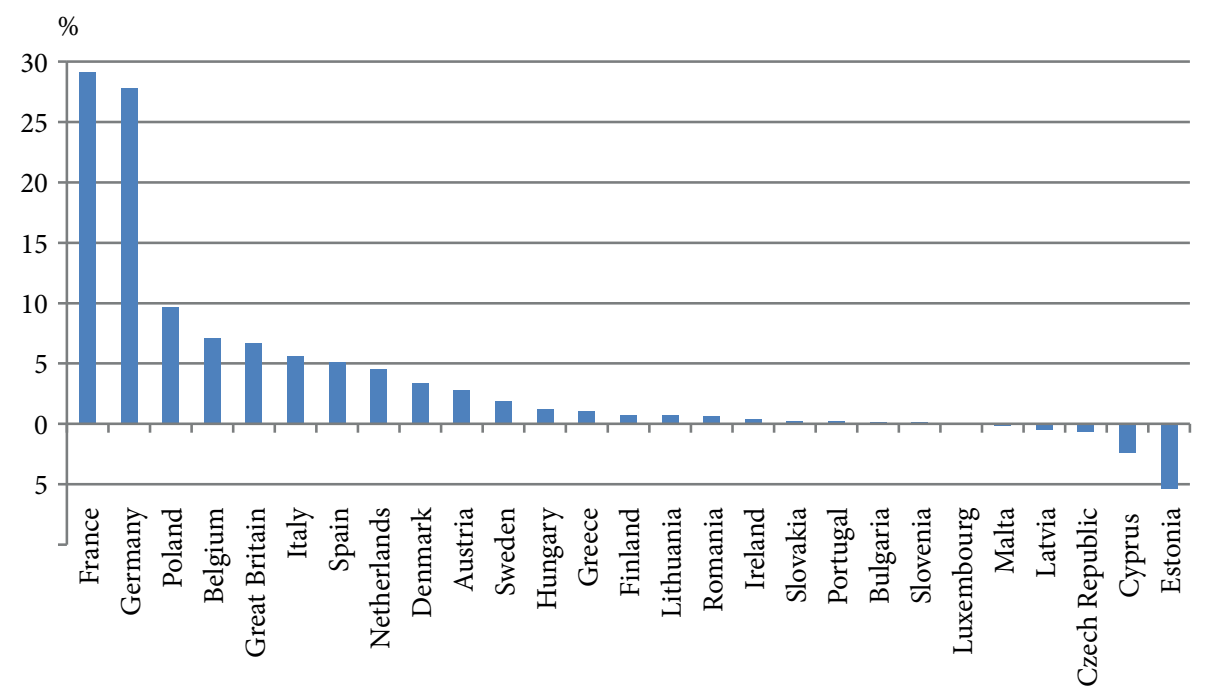

Figure 4. Average share of EU Member States in the payments of sugar levies in the years 2005-2013 (excluding Croatia, \%)

Source: based on (European Commission, 2014b).

EUR 194 million in 2011 to almost EUR 270 million in 2013, however their fiscal performance remained very low-at $0.18 \%$.

The share of Member States in sugar levies is very diverse and depends on the size of the sugar sector. Figure 4 shows the average share of EU Member States in the revenues from sugar levies in the years 2005-2013.

Until 2004 the main payers were Germany and France. For example in the years 2000-2004 the average share of these countries in total revenues from levies amounted to 31.4 and $27.9 \%$, respectively ${ }^{6}$. In the case of other countries this share did not exceed 7.5\% with Luxembourg not paying any such levies at all. From 2005 Poland joined the group of major payers. The negative shares of some countries result from the quotient of their payments and negative total revenues from sugar levies in 2007. Unlike other countries they were not entitled to a refund. It can therefore be assumed that these countries, through budget redistribution, financed the refunds of levies to other states to a certain extent .

\section{Losses of Member States for the abolition of administrative costs for the collection of sugar levies}

The fiscal consequences of the abolition of sugar levies for Member States are expressed primarily in:

\footnotetext{
${ }^{6}$ Calculations based on European Commission (2014b).
} 
- loss of net revenue from administrative expenses for the collection of sugar levies,

- change in the GNI burden,

- change in the operating balance relative to the EU budget.

The loss of net revenue from administrative costs of collecting sugar charges results from the fact that the determined costs of collecting these levies $(25 \%$ of funds collected) significantly exceed the costs actually incurred. Actual tolling costs can be related to the costs of national tax assessment and collection by Member States and, for example, in 2000-2010 they were at an average level of $0.46 \%$ of collected tax revenues in Sweden to 5.96\%-in Cyprus. The average for all Member States amounted to $1.21 \%$ in this period. The analysis assumed that the actual loss of revenue for a given country is the difference between the costs set by the Union and the actual average cost of collecting national taxes in the years 2000-2010. The analysis additionally assumes:

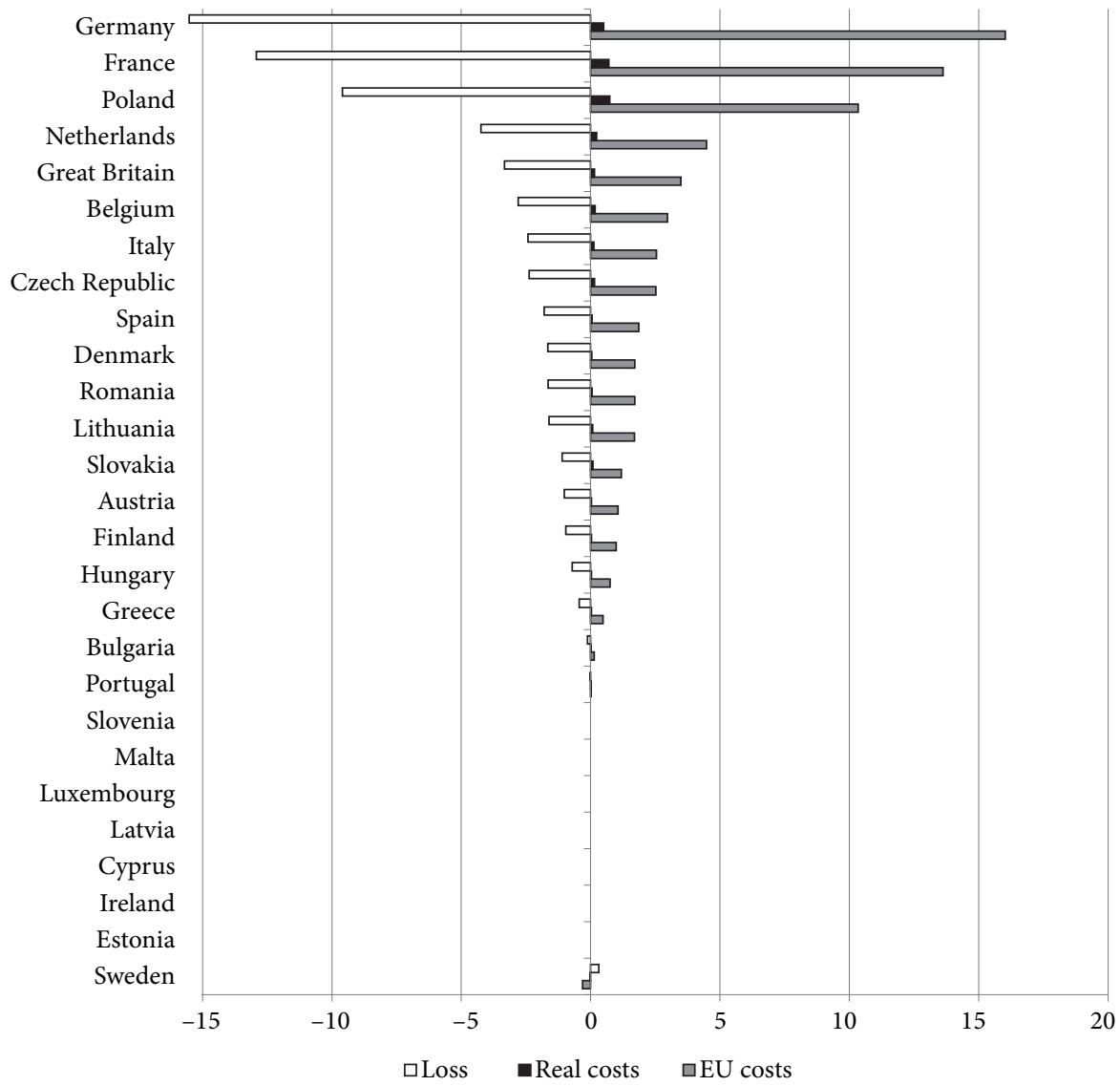

Figure 5. Lost revenue from administrative costs for sugar levies in 2013 (excluding Croatia, EUR million)

Source: based on (European Commission, 2014b; Cieślukowski, 2013). 
- loss of revenue from sugar levies will be compensated by a reduction in expenses on the sugar market. The Union therefore does not foresee additional adjustments to Member States burdens,

- the estimation of changes was made in the budget conditions in force in 2013, ie after the reforms and stabilization of the internal sugar market.

The evolution of lost revenues of member states in 2013 is presented in Figure 5.

Figure 5 shows that the largest producers of sugar products bear the biggest losses, namely Germany (over EUR 15.5 millions), France (nearly EUR 13.0 millions) and Poland (nearly EUR 9.6 millions). Sweden exceptionally in 2013 received a refund of sugar levies of EUR 1.3 million, which gives savings in costs of about EUR 0.3 million. The reform is neutral for countries that do not produce sugar products.

\section{Change in the burden on Member States for GNI payments}

In this case the main unknown is the method of covering expenses on the sugar market after the abolition of sugar levies. Such expenditures will occur as the 2006 sector reform replaced the mechanism for supporting the prices of direct payments for growers which are entirely financed from the European Agricultural Guarantee Fund and thus from the general budget. At the same time Figure 1 shows that after 2010 the amount of direct payments exceeds the revenue from sugar levies. The analysis assumes the following:

- loss of revenue from sugar levies will be compensated by additional payments from Member States for GNI,

- Member States' GNI contributions have been set in proportion to their EU GNI share,

- the analysis was carried out under the fiscal conditions in force in 2013. Total net revenues from sugar levies (lost revenues) was EUR 268.8 million this year.

The simulation of the payments in question in the cross-section of Member States in 2013 is shown in Figure 6.

Figure 6 shows that the main sugar producers gain first of all on the change in the burden. The benefits are all the greater the greater the share of a given country in the financing of sugar levies from the participation in financing revenue from GNI. Poland is in the best situation in this respect and which in 2013 provided over 15\% of total revenues from sugar levies, while its share in creating revenues from GNI was only $2.8 \%$. On the other hand, in a different situation, there are countries whose shares in creating revenue from sugar levies are lower than their share in generating revenue from GNI. In 2013 they mainly include Great Britain, Italy, Spain and Sweden. It should be noted that 


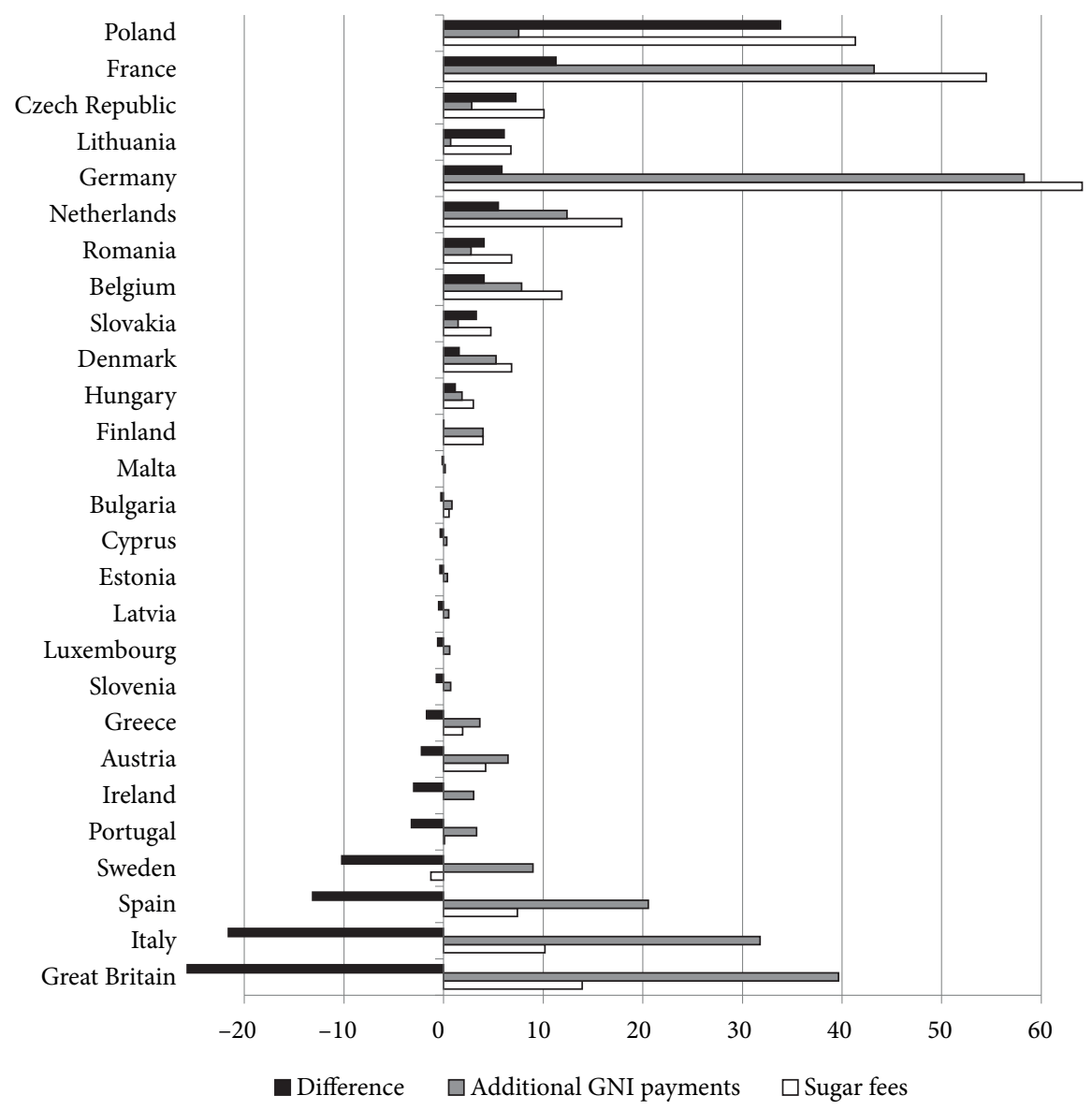

Figure 6. Simulation of additional payments by Member States for GNI in 2013 (excluding Croatia, EUR million)

Source: based on (European Commission, 2014b).

an additional fiscal burden is also created for those countries that have not paid sugar levies before (Cyprus, Estonia, Ireland, Luxembourg, Malta, Slovenia).

\section{Changes in the operating balance}

The tax burden has deep implications on the economy, influencing the economic growth and, at the same time, the welfare inequality as an effect of the revenue distribution (Tiwari \& Mutascu, 2014). The European Union does not impose real taxes on companies or Member States but receives so-called own resources from them. The fair distribution of the fiscal burden is one of the most important and the most difficult conditions for agreement between Member States 
regarding own resources (High Level Group, 2014). Unfortunately no objective and timeless method of measuring this justly has been developed so far. As a consequence the agreement is often achieved through negotiations that take into account the interests and priorities of individual countries. ${ }^{7}$ In the subject literature the justice discussed is considered in two fundamental approaches, i.e. horizontal justice and vertical justice, each of which can still be analyzed not only from the point of view of states, but also of their inhabitants (High Level Group, 2014; Cieślukowski, 2013; Cattoir, 2009; Begg \& Grimwade 1998). In the previous reports on own revenue the European Commission exposes rather a horizontal form of justice understood generally in such a way that countries with similar economic potential should experience a similar fiscal burden and which should be proportional to the economic potential measured by the share of a given country in the Union's GNI (European Commission 2011b, p. 41; European Commission 2004, pp. 64-65; European Commission 1998, p. 6). However the fiscal burden itself is measured differently. Until the end of the previous century it was mainly measured by the share of GNI and VAT in total budget revenues ${ }^{8}$ (gross method), while it is currently expressed in the share of the country's operating balance in GNI (the net method). In both cases excessive burdens are reduced by means of various correction mechanisms incorporated into revenues (e.g. costs of collecting traditional revenues, limiting the VAT base, temporary quota rebates). However empirical data indicate that the increasing share of GNI revenue in total budget revenues (e.g. in 2013, this share amounted to almost 74\%) favours the justice achieved using the gross method. On the other hand the management of the operating balance, with unevenly distributed expenditures between Member States, makes it more difficult to achieve satisfactory burden sharing and rather serves the main payers to recover the amounts paid, rather than to achieve a fair share of burdens.

Point five shows that the abolition of sugar levies will result in changes in the structure of Member States' burdens due to GNI payments. Figure 7 shows the difference in the share of Member States' operating balance in their GNI in 2013 before and after the abolition of sugar levies.

The analysis assumes that after the abolition of sugar levies the annual allowances for GNI payments granted to the Member States will not change (the Netherlands-EUR 605 million, Sweden-EUR 150 million, the reduction of payments for the UK (the UK rebate) by Austria, Germany, the Netherlands and Sweden to a quarter of the original size), while these payments will be increased by lost administrative costs due to sugar levies.

\footnotetext{
${ }^{7}$ This is evidenced by the differences between the European Commission's proposals on own revenues and the final decisions of the EU Council.

${ }^{8}$ The net operating balance of the state is the difference between expenditures for a given country, excluding administrative expenses, and the sum of the proceeds from GNI and VAT obtained from it (European Commission, 2014b).
} 


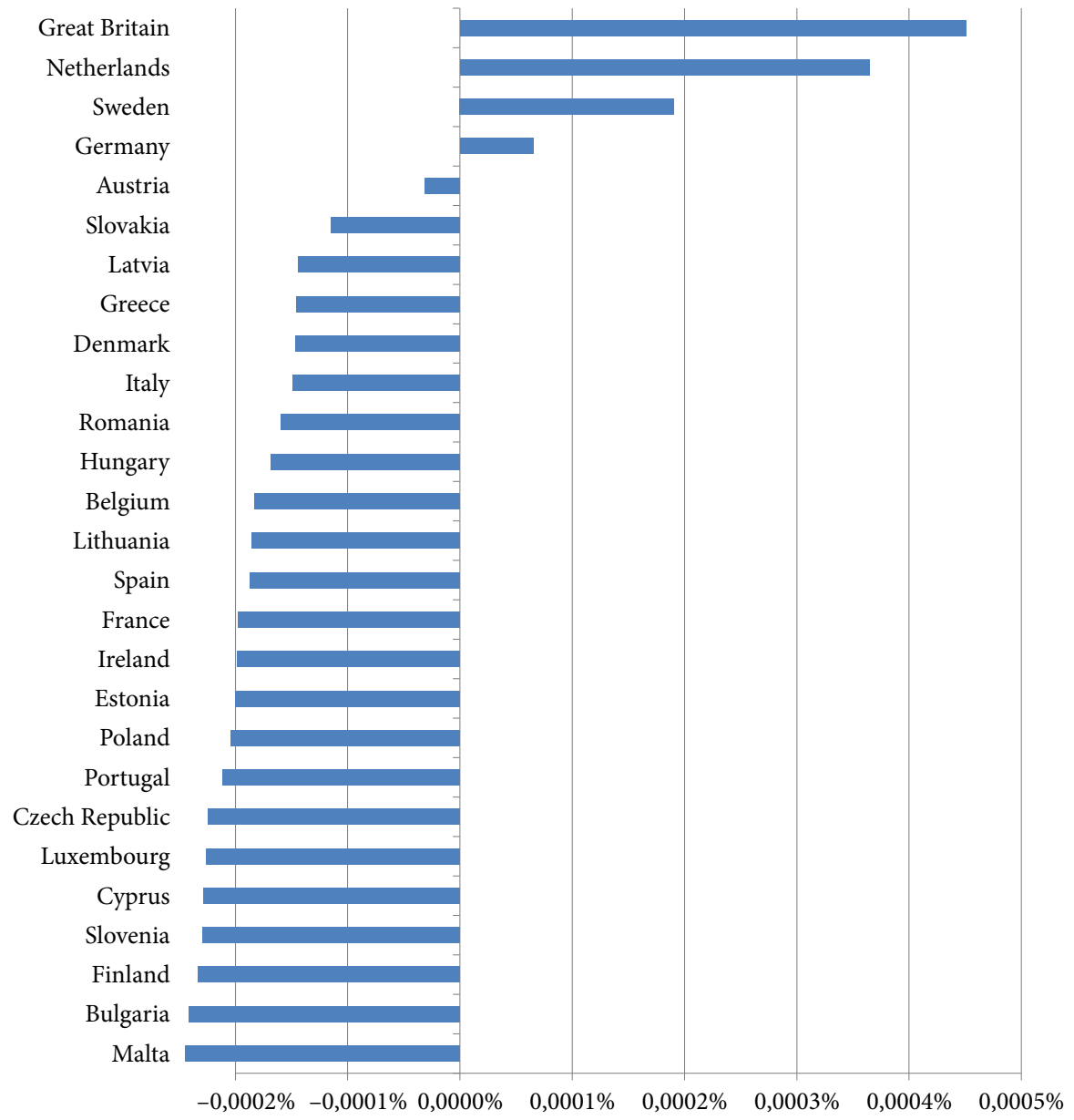

Figure 7. Difference in the share of Member States' net operating balance in their GNI in 2013 before and after the abolition of sugar charges (\% of GNI) Source: based on (European Commission, 2014b).

Figure 7 shows that changes in the Member States' balance of accounts in relation to GNI caused by the replacement of sugar charges by additional GNI payments are marginal. Nevertheless the biggest adverse effects of the reform were recorded by countries such as Great Britain, the Netherlands and Sweden, i.e. those that are not the main payers of sugar levies, but are the main net contributors to the EU budget and benefit from GNI contributions. The negative effects of the reform were also felt by Germany which is the largest total net payer and benefits from GNI payments. Germany noted in contrast to the countries previously mentioned, financial benefits of the implemented reform of EUR 5.8 million (Figure 6). Other countries slightly improved their financial situation vis-à-vis the EU budget. 


\section{Conclusions}

The article identifies the fiscal effects of the abolition of sugar levies. The European Union will lose some of its budget revenues while the Member States will lose their revenue resulting from the difference between $25 \%$ of their administrative costs and the much lower actual costs of collecting these levies. Due to the poor fiscal performance of sugar levies these losses do not significantly deteriorate the fiscal situation of the audited entities. The largest payers of these levies, including Poland, do not have the largest losses. The inclusion of sugar beet growers in direct payments with the abolition of sugar charges contributes to the need for additional financial resources. Covering these costs by Member States' payments for GNI will result in some changes in the structure of the burden on these countries as well as changes in their operating balance relative to the EU budget. Through these changes Poland will gain, on the other hand, those countries that are not essential producers of sugar will lose, including primarily, Great Britain, the Netherlands and Sweden. Additional burdens are not high, but taking into account the negative attitude of these countries to increasing payments, they may be the subject of dispute in the Council and translate into another manipulation of relief in payments.

Regarding the policy implications the results are useful for both European Union members and their country's policymakers. On the one hand public authorities should take into account the minimal sensitivity of budget revenues caused by the abolition of sugar levies. On the other hand, such adjustment seems to generate negative effects in countries that are not the main producers of sugar.

\section{References}

Agencja Rynku Rolnego. (2004). Realizacja Mechanizmu WPR. Opłaty cukrowe. Zasady pobierania opłat cukrowych. Warszawa: Agencja Rynku Rolnego.

Begg, I. \& Grimwade, N. (1998). Paying for Europe. Sheffield: Sheffield Academic Press. Cattoir, P. (2009). Options for an EU financing reform. Notre Europe, Policy Paper, 38. Comité Européen des Fabricants de Sucre. (2010). The European sugar sector. Brussels: Comité Européen des Fabricants de Sucre.

Cieślukowski, M. (2013). Wielokryterialna ocena systemu zasobów własnych Unii Europejskiej. Poznań: Wydawnictwo Uniwersytetu Ekonomicznego w Poznaniu.

Council Decision of 21 April 1970 on the replacement of financial contributions from Member States by the Communities' own resources, OJ L 094.

Council Regulation of 20 February 2006 establishing a temporary scheme for the restructuring of the sugar industry in the Community and amending Regulation (EC) No 1290/2005 on the financing of the common agricultural policy, OJ L58.

Council Regulation of 16 December 2013 determining measures on fixing certain aids and refunds related to the common organisation of the markets in agricultural products, OJ L 346. 
Directorate-General Agriculture and Rural Development. (2011). Evaluation of Cap Measures Applied to the Sugar Sector. European Commission, Final Report.

Directorate-General Budget. Budget on line. Retrieved January 27, 2017 from http:// eur-lex.europa.eu/budget/www/index-pl.htm

Etapy reform rynku cukru. (2011). Warszawa: Ministerstwo Rolnictwa i Rozwoju Wsi.

European Commission. (1998). Financing the European Union. Commission report on the operation of the own resources system, commission of the European communities. Brussels: COM 560 final.

European Commission. (2004). Financing the European Union. Commission report on the operation of the own resources system. Brussels: COM 505 final, vol. II, Technical Annex.

European Union. (2006). Financial Report 2005. Luxembourg: European Union.

European Commission. (2008a). 1st Financial Report from the Commission to the European Parliament and the Council on the European Agricultural Guarantee Fund2007 financial year. Brussels: COM 587 final.

European Commission. (2008b). EU budget 2007 Financial Report. Luxembourg: European Communities.

European Commission. (2011a). Evaluation of cap measures applied to the sugar sector. DG Agriculture and Rural Development, Final Report.

European Commission. (2011b). Financing the EU Budget: Report on the operation of the own resources system. Commission Staff Working Paper, Brussels: SEC 876 final.

European Commission. (2013). Overview of CAP Reform 2014-2020. European Union.

European Commission. (2014a). 7th Financial Report from the Commission to the European Parliament and the Council on the European Agricultural Guarantee Fund2013 financial year. Brussels: COM 561 final.

European Commission. (2014b). EU budget 2013. Financial Report. Luxembourg: European Commission.

High Level Group. (2014). High level group own resources first assessment report. European Commission.

Tiwari, A. \& Mutascu, M. (2014). A revisit on the tax burden distribution and GDP growth: Fresh evidence using a consistent nonparametric test for causality for the USA. Empirical Economics, 46(3), 961-972.

World Trade Organization. (2016). The WTO agreements series agriculture (3rd edition). World Trade Organization. 